\title{
CTNNA1 wt Allele
}

National Cancer Institute

\section{Source}

National Cancer Institute. CTNNA1 wt Allele. NCI Thesaurus. Code C88986.

Human CTNNA1 wild-type allele is located in the vicinity of 5q31 and is approximately 210

$\mathrm{kb}$ in length. This allele, which encodes catenin alpha-1 protein, plays a role in the

mediation of both protein-protein interactions and cellular adhesion. 